ПОЛЕНКОВА

Марина Володимирівна
УДК 636:164.23:(631.151)

СУЧАСНИЙ СТАН І ТЕНДЕНЦЇ̈ РОЗВИТКУ АГРАРНИХ ПІДПРИЕМСТВ, ЩО СПЕЦІАЛЗУЮТЬСЯ НА ТВАРИННИЦТВІ В УКРАЇНІ

\title{
CURRENT STATE AND TRENDS OF DEVELOPMENT OF AGRICULTURAL ENTERPRISES SPECIALIZING IN LIVESTOCK IN UKRAINE
}

к.е.н., дочент, завідувачка кафедри, Начуінальний

університет "Чернігівська політехніка"

POLENKOVA Maryna Volodymyrivna - PhD in Economics, Associate Professor, Head of the department, National University "Chernihiv Polytechnic"

У статті охарактеризовано сучасний стан галузі тваринництва та проблеми, щчо ї̈ супроводжують. Проаналізовано обсяги вирощування та реалізаиії на забій сільськогосподарських тварин, а також обсяги виробництва молока, яєць, вовни, меду. Виявлено вагомі структурні зміни упродовж 2000-2019 рр. у виробництві м'яса аграрними підприємствами. Проведено кластеризацію регіонів України за схожими умовами розвитку підприємств аграрного сектору, шзо спеціалізуються на тваринництві. За результатами аналізу виокремлено 4 кластери, щзо дало привід стверджувати про можливість формування (розроблення) спільних ефективних організаційно-економічних механізмів стосовно активізації розвитку підприємств тваринництва, сприятливих для впровадження в межах кластера.

$$
* * *
$$

В статье охарактеризовано современное состояние отрасли животноводства и проблемы, что ее сопровождают. Проанализированы объемы выращчивания и реализации на убой сельскохозяйственных животных, а также объемы производства молока, яиц, иерсти, меда. Выявлено веские структурные изменения в течение 2000 -2019 г2. в производстве мяса аграрными предприятиями. Проведения кластеризации регионов Украины по сходньм условиям развития предприятий аграрного сектора, специиализируюшчися на животноводстве. По результатам анализа выделены 4 кластера, что дало повод утверждать о возможности формирования (разработки) совместных эффективных организационно-экономических механизмов по активизации развития предприятий животноводства, благоприятных для внедрения в пределах кластера.

$$
* * *
$$

The paper describes the current state of the livestock industry and the problems that accompany it. The volumes of cultivation and sale for slaughter of farm animals, as well as the volumes of production of milk, eggs, wool, honey are analyzed. Significant structural changes during 2000-2019 in meat production by agricultural enterprises were revealed. The clustering of regions of Ukraine under similar conditions of development of the enterprises of the agricultural sector specializing in animal husbandry is carried out. According to the results of the analysis, 4 clusters were identified, which gave rise to the possibility of forming (developing) joint effective organizational and economic mechanisms to intensify the development of livestock enterprises, favorable for implementation within the cluster.

Sustainable development of agriculture, including livestock, is essential to reduce poverty and ensure food security and nutrition, designed to meet the growing demand of the world's growing population for safe and guaranteed affordable food of animal origin, which is grown in compliance with increasingly stringent requirements, while protecting the environment.

In the process of this study, attention is focused on the development trends of enterprises specializing in animal husbandry. The current state of the livestock industry is characterized by a number of problems, manifested in the following:

- imbalance in the development of the agricultural sector: livestock significantly lags behind in terms of development compared to the crop sector;

- low level of commodity production: the share of households in the production of livestock products, especially in the livestock sector, remains decisive;

- low investment attractiveness: high cost of money in combination with a long payback period constrains investment in the development of the industry;

- Insufficient level of consumption: consumption of meat and dairy products per 1 person is lower than reasonable norms;

- a threatening epizootic situation: the spread of African swine fever threatens the entire pig industry.

The application of multifactor statistical (cluster) analysis made it possible to group the regions of Ukraine under similar conditions for the development of agricultural enterprises specializing in animal husbandry. This provides opportunities for the formation (development) of joint effective organizational and economic mechanisms to enhance the development of livestock enterprises, favorable for implementation within each cluster (subject to the specifics of each region).

Ключові слова: продукція тваринництва, аграрні підприємства, сільське господарство, регіони

Ключевые слова: продукция животноводства, аграрные предприятия, сельское хозяйство, регионы

Keywords: livestock products, agricultural enterprises, agriculture, regions

\section{ВСТУП}

Сталий розвиток сільського господарства, тваринництва зокрема, має істотне значення для скорочення масштабів бідності та забезпечення продовольчої безпеки й харчування, покликаний безперебійно задо- вольняти попит зростаючого населення світу на безпечні та гарантовано доступні продукти харчування тваринного походження, що вирощуються 3 дотриманням усе більш жорстких вимог, в одночасному захисті довкілля. 
Для задоволення майбутніх потреб у продовольстві зростання обсягів виробництва повинно забезпечуватися головно за рахунок більш інтенсивного й більш ефективного використання земельних і водних ресурсів, генетичного потенціалу рослин і тварин, а також рибних і лісових ресурсів, наявних у розпорядженні аграрних підприємств.

Встановлено, що комплексні й цілісні підходи із залученням місцевого населення сприяють зростанню випуску тваринницької продукції. Синергетичні зв'язку, що з'являються в результаті інтеграції виробничих систем рослинництва і тваринництва, відкривають численні можливості для участі аграрних підприємств і домашніх господарств у процесі неухильного підвищення продуктивності та ефективності використання ресурсів. На частку змішаних рослинницькотваринницьких сільських господарств припадає близько половини обсягу світового виробництва продуктів харчування. У таких системах продукція, вироблена на одному з етапів, стає сировиною на іншому етапі, водночас витік речовин у навколишнє середовище, наприклад, у вигляді викидів парникових газів може зводитися до мінімуму. Відтак обраний напрям дослі- дження вважаємо актуальним.

МЕТА роботи - визначення тенденцій розвитку аграрних підприємств, що спеціалізуються на тваринництві в Україні.

\section{РЕЗУЛЬТАТИ}

$\mathrm{У}$ процесі даного дослідження акцентуємо увагу на тенденціях розвитку підприємств, що спеціалізуються на тваринництві. Сучасний стан галузі тваринництва характеризується низкою проблем, що проявляються в наступному:

- незбалансованість розвитку аграрного сектору: тваринництво суттєво відстає за темпами розвитку порівняно з галуззю рослинництва $(0,4 \%$ - середньорічний темп зростання виробництва у тваринництві за останні 10 років проти $4,8 \%$ у рослинництві) $[1,2]$;

- низький рівень товарного виробництва: частка господарств населення у виробництві продукції тваринництва, особливо в галузі скотарства, залишається визначальною ( $72 \%$ - частка у виробництві молока та яловичини господарствами населення, проте лише $12 \%$ надходить на переробку) (табл. 1-3);

Таблиця 1

Обсяги вирощування сільськогосподарських тварин (у живій масі, тис. т) [сформовано за [1,2]]

\begin{tabular}{|c|c|c|c|c|c|c|}
\hline & 2000 & 2010 & 2015 & 2017 & 2018 & 2019 \\
\hline \multicolumn{7}{|c|}{ Підприємства } \\
\hline Сільськогосподарські тварини & 556,4 & 1638,5 & 2038,5 & 2056,5 & 2220,1 & 2331,1 \\
\hline велика рогата худоба & 371,0 & 174,6 & 155,6 & 151,4 & 145,2 & 143,9 \\
\hline свині & 117,6 & 411,8 & 583,8 & 531,3 & 529,6 & 546,1 \\
\hline вівці та кози & 3,2 & 3,5 & 2,3 & 2,3 & 2,6 & 2,2 \\
\hline птиця свійська всіх видів & 58,7 & 1047,2 & 1294,5 & 1369,7 & 1541,2 & 1637,3 \\
\hline кролі & 0,0 & 0,5 & 1,9 & 1,5 & 1,2 & 1,1 \\
\hline коні & 5,9 & 0,9 & 0,4 & 0,3 & 0,3 & 0,5 \\
\hline \multicolumn{7}{|c|}{ фермерські господарства зокрема } \\
\hline Сільськогосподарські тварини & 9,8 & 73,1 & 78,6 & 79,8 & 87,5 & 97,8 \\
\hline велика рогата худоба & 6,9 & 9,9 & 12,1 & 12,3 & 12,6 & 12,7 \\
\hline свині & 2,6 & 27,5 & 30,0 & 29,6 & 28,4 & 31,4 \\
\hline вівці та кози & 0,0 & 0,4 & 0,2 & 0,3 & 0,2 & 0,2 \\
\hline птиця свійська всіх видів & 0,1 & 35,3 & 36,2 & 37,5 & 46,3 & 53,5 \\
\hline кролі & 0,0 & 0,0 & 0,1 & 0,1 & 0,0 & 0,0 \\
\hline коні & 0,2 & 0,0 & 0,0 & 0,0 & 0,0 & 0,0 \\
\hline \multicolumn{7}{|c|}{ Господарства населення } \\
\hline Сільськогосподарські тварини & 1721,6 & 1298,2 & 1161,9 & 1149,6 & 1148,1 & 1114,4 \\
\hline велика рогата худоба & 719,1 & 479,2 & 447,0 & 417,2 & 419,5 & 412,5 \\
\hline свині & 724,2 & 503,7 & 440,2 & 454,2 & 436,0 & 420,8 \\
\hline вівці та кози & 35,8 & 37,2 & 25,9 & 25,1 & 26,5 & 24,1 \\
\hline птиця свійська всіх видів & 206,2 & 231,6 & 210,8 & 216,5 & 229,0 & 222,0 \\
\hline кролі & 27,8 & 26,7 & 24,6 & 22,9 & 23,1 & 22,1 \\
\hline коні & 8,5 & 19,8 & 13,4 & 13,7 & 14,0 & 12,9 \\
\hline
\end{tabular}


Обсяги реалізації на забій сільськогосподарських тварин (у живій масі, тис. т) [сформовано за [1, 2]]

\begin{tabular}{|c|c|c|c|c|c|c|}
\hline & 2000 & 2010 & 2015 & 2017 & 2018 & 2019 \\
\hline \multicolumn{7}{|c|}{ Підприємства } \\
\hline Сільськогосподарські тварини & 718,5 & 1530,7 & 1976,7 & 2013,2 & 2079,2 & 2299,7 \\
\hline \multicolumn{7}{|l|}{ за видами зокрема } \\
\hline велика рогата худоба & 531,2 & 177,9 & 158,3 & 160,6 & 148,5 & 171,7 \\
\hline свині & 127,5 & 350,4 & 550,1 & 515,5 & 499,8 & 527,1 \\
\hline вівці та кози & 5,3 & 2,6 & 1,8 & 2,4 & 2,5 & 2,6 \\
\hline птиця свійська всіх видів & 48,6 & 998,4 & 1264,2 & 1332,9 & 1426,9 & 1596,7 \\
\hline кролі & 0,0 & 0,5 & 1,9 & 1,5 & 1,2 & 1,1 \\
\hline коні & 5,9 & 0,9 & 0,4 & 0,3 & 0,3 & 0,5 \\
\hline \multicolumn{7}{|c|}{ фермерські господарства зокрема } \\
\hline Сільськогосподарські тварини & 13,8 & 64,8 & 72,2 & 81,3 & 82,6 & 94,5 \\
\hline \multicolumn{7}{|l|}{ за видами зокрема } \\
\hline велика рогата худоба & 10,1 & 9,7 & 13,7 & 16,8 & 12,9 & 13,7 \\
\hline свині & 3,1 & 19,7 & 25,7 & 28,1 & 26,1 & 27,5 \\
\hline вівці та кози & 0,1 & 0,3 & 0,0 & 0,3 & 0,1 & 0,3 \\
\hline птиця свійська всіх видів & 0,3 & 35,1 & 32,7 & 36,0 & 43,5 & 53,0 \\
\hline кролі & 0,0 & 0,0 & 0,1 & 0,1 & 0,0 & 0,0 \\
\hline коні & 0,2 & 0,0 & 0,0 & 0,0 & 0,0 & 0,0 \\
\hline \multicolumn{7}{|c|}{ Господарства населення } \\
\hline Сільськогосподарські тварини & 1889,0 & 1394,7 & 1293,7 & 1253,7 & 1238,4 & 1193,9 \\
\hline \multicolumn{7}{|l|}{ за видами зокрема } \\
\hline велика рогата худоба & 784,8 & 549,3 & 493,6 & 456,7 & 461,4 & 454,7 \\
\hline свині & 820,3 & 511,6 & 498,1 & 506,1 & 479,1 & 449,2 \\
\hline вівці та кози & 33,5 & 40,4 & 27,1 & 26,2 & 27,3 & 25,9 \\
\hline птиця свійська всіх видів & 214,1 & 246,9 & 236,9 & 228,1 & 233,5 & 229,1 \\
\hline кролі & 27,8 & 26,7 & 24,6 & 22,9 & 23,1 & 22,1 \\
\hline коні & 8,5 & 19,8 & 13,4 & 13,7 & 14,0 & 12,9 \\
\hline
\end{tabular}

Обсяги виробництва молока, яєць, вовни, меду [сформовано за [1, 2]]

\begin{tabular}{|l|r|r|r|r|r|r|}
\hline & \multicolumn{1}{|c|}{2000} & \multicolumn{1}{c|}{2010} & \multicolumn{1}{c|}{2015} & 2017 & 2018 & 2019 \\
\hline \multicolumn{7}{|c|}{ Підприємства } \\
\hline Молоко (тис. т) & 3668,7 & 2216,6 & 2669,2 & 2765,7 & 2755,5 & 2728,6 \\
\hline Яйця (млн шт) & 2977,3 & 10249,6 & 9762,2 & 8365,3 & 8900,3 & 9357,6 \\
\hline Вовна (т) & 1311 & 710 & 314 & 255 & 236 & 200 \\
\hline Мед (т) & 3564 & 1620 & 918 & 847 & 890 & 787 \\
\hline & фермерські господарства зокрема & \\
\hline Молоко (тис. т) & 67,8 & 112,1 & 177,4 & 194,8 & 201,8 & 209,2 \\
\hline Яйця (млн шт) & 6,7 & 78,4 & 75,5 & 89,1 & 117,2 & 134,3 \\
\hline Вовна (т) & 9 & 128 & 69 & 55 & 57 & 49 \\
\hline Мед (т) & 83 & 215 & 120 & 111 & 120 & 98 \\
\hline & \multicolumn{7}{|c|}{ Господарства населення } \\
\hline Молоко (тис. т) & 8989,2 & 9031,9 & 7946,2 & 7514,8 & 7308,5 & 6934,6 \\
\hline Яйця (млн шт) & 5831,3 & 6802,7 & 7020,7 & 7140,5 & 7231,7 & 7319,9 \\
\hline Вовна (т) & 2089 & 3482 & 1956 & 1712 & 1672 & 1534 \\
\hline Мед (т) & 48875 & 69253 & 62697 & 65384 & 70389 & 69150 \\
\hline
\end{tabular}


- низька інвестиційна привабливість: висока вартість грошей у поєднанні 3 довгим періодом окупності інвестицій стримують капіталовкладення в розвиток галузі (-10\% капітальних інвестицій у сільському, лісовому та рибному господарстві й лише 9,4 \% частка тваринництва);

- недостатній рівень споживання: споживання м'ясо-молочної продукції на 1 особу є нижчим за обгрунтовані норми (53\% від норми споживання молока, 67 \% від норми споживання м'яса);

- загрозлива епізоотична ситуація: поширення африканської чуми свиней ставить під загрозу всю галузь свинарства (492 випадки за 2015-2019 рр.; $-19 \%$ (-1,3 млн голів) - скорочення поголів'я свиней упродовж 2015-2019 pp.

Важливо відзначити також вагомі структурні зміни у перебігу 2000-2019 рр. у виробництві м'яса аграрними підприємствами. Значного скорочення зазнала частка виробництва яловичини й телятини $(-63,7 \%)$; натомість суттєво зросла частка виробництва м'яса птиці (63\%) (рис. 1).

У процесі дослідження вважаємо доцільним визначити схожі умови (середовища, ресурсного забезпечення тощо) стосовно розвитку аграрних підприємств, що спеціалізуються на тваринництві між регіонами України. Для цього застосовано багато факторний статистичний (кластерний) аналіз ключових чинників їх функціонування на основі матриці із 16 відібраних індикаторів розвитку підприємств, що спеціалізуються на тваринництві $\left(a_{l}\right.$ - вирощування великої рогатої худоби на підприємствах; $a_{2}$ - вирощування свиней на підприємствах; $a_{3}$ - вирощування птиці свійської всіх видів на підприємствах; $a_{4}$ - реалізація на забій великої рогатої худоби на підприємствах; $a_{5-}$ реалізація на забій свиней на підприємствах; $a_{6}$ - реалізація на забій птиці свійської всіх видів на підприємствах; $a_{7}$ - виробництво м'яса всіх видів на підприємствах; $a_{8}$ - виробництво яловичини та телятини на підприємствах; $a_{9}$ - виробництво свинини на підприємствах; $a_{10}$ - виробництво м'яса птиці свійської всіх видів на підприємствах; $a_{11}$ - виробництво молока всіх видів на підприємствах; $a_{12}$ середній річний удій молока від однієї корови на підприємствах; $a_{13}$ - виробництво яєць від птиці свійської всіх видів на підприємствах; $a_{14}$ - виробництво м'яса на одну особу; $a_{15}$ - виробництво молока на одну особу; $a_{16}$ - виробництво яєць на одну особу) за всіма регіонами (384 показника). Для посилення об'єктивності результатів аналіз проводився окремо за 2010 р., 2015 р. та 2019 р.

За результатами аналізу виокремлено таксономічні групи (кластери), що дало можливість відзначити схожі регіональні умови в межах кожної групи (рис. 2).

Упродовж десяти років відбулися значні зміни в регіональному розподілі аграрного потенціалу у сфері тваринництва в Україні. Навіть протягом 2015-2019 рр. простежується розбіжності щодо ресурсного забезпечення та використання в межах конкретних кластерів (рис. 3).

ПIДПРИЕМСТВА

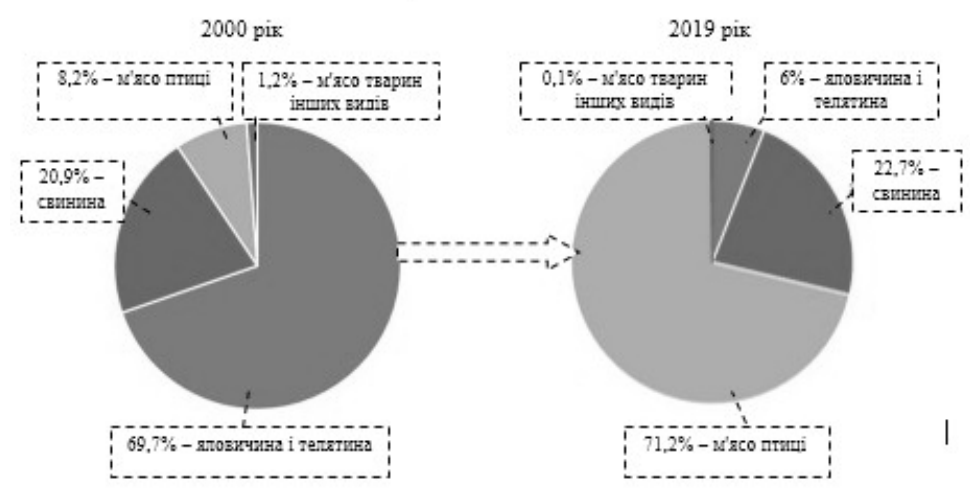

ГОСПОДАРСТВА НАСЕЛЕННЯ

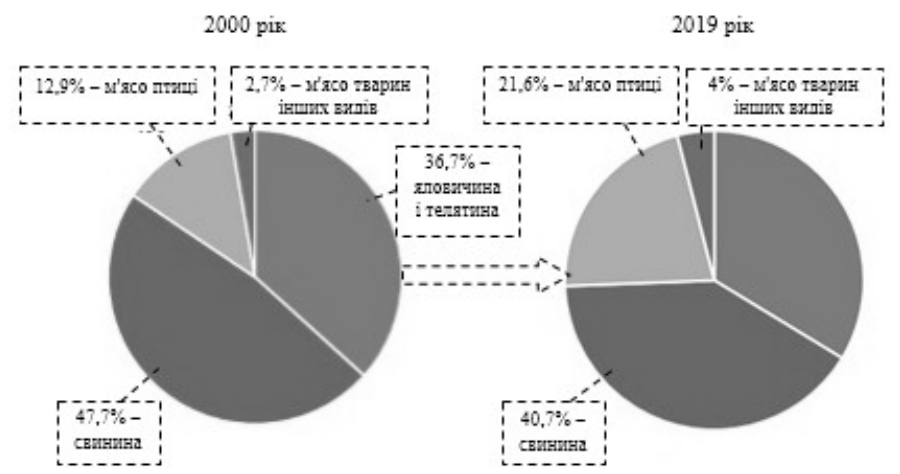

Рис. 1. Структура виробництва м'яса підприємствами та господарствами населення (\% до загального обсягу виробництва) [складено за [1, 2]] 

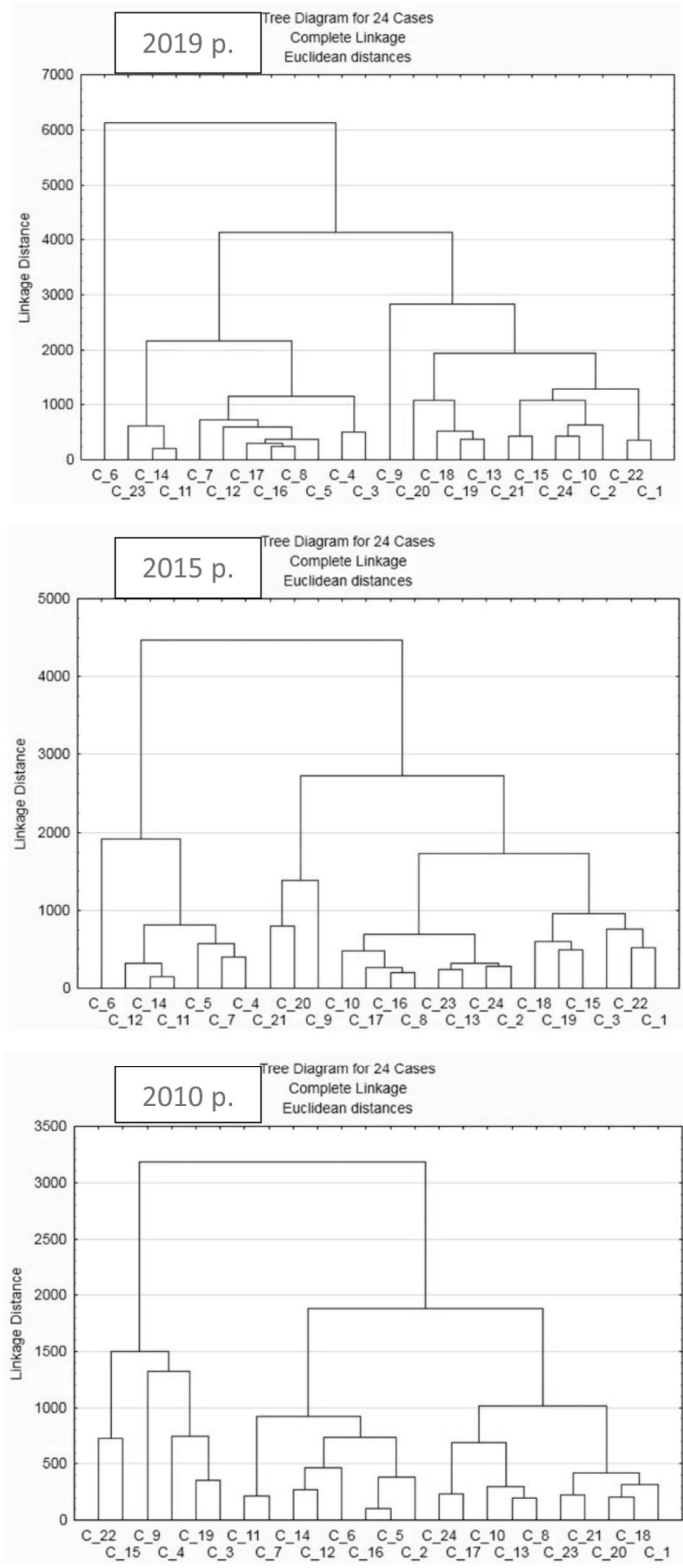

де C_1 - Вінницька; С_2 - Волинська; С_3 - Дніпропетровська; C_4 - Донецька; С_5 - Житомирська; С_6 Закарпатська; С 7 - Запорізька; С 8 - Івано-Франківська; С 9 - Київська; С 10 - Кіровоградська; С 11 - Луганська; С 12 Львівська; C_13 - Миколаївська; C_14 - Одеська; C_15- Полтавська; C_16 - Рівненська; C_17 - Сумська; С_18 Тернопільська; C_19 - Харківська; C_20 - Херсонська; С_21 - Хмельницька; С_22 - Черкаська; С_23 - Чернівецька; C_24 Чернігівська області.

Рис. 2. Результати багатофакторного статистичного аналізу [розраховано автором] 


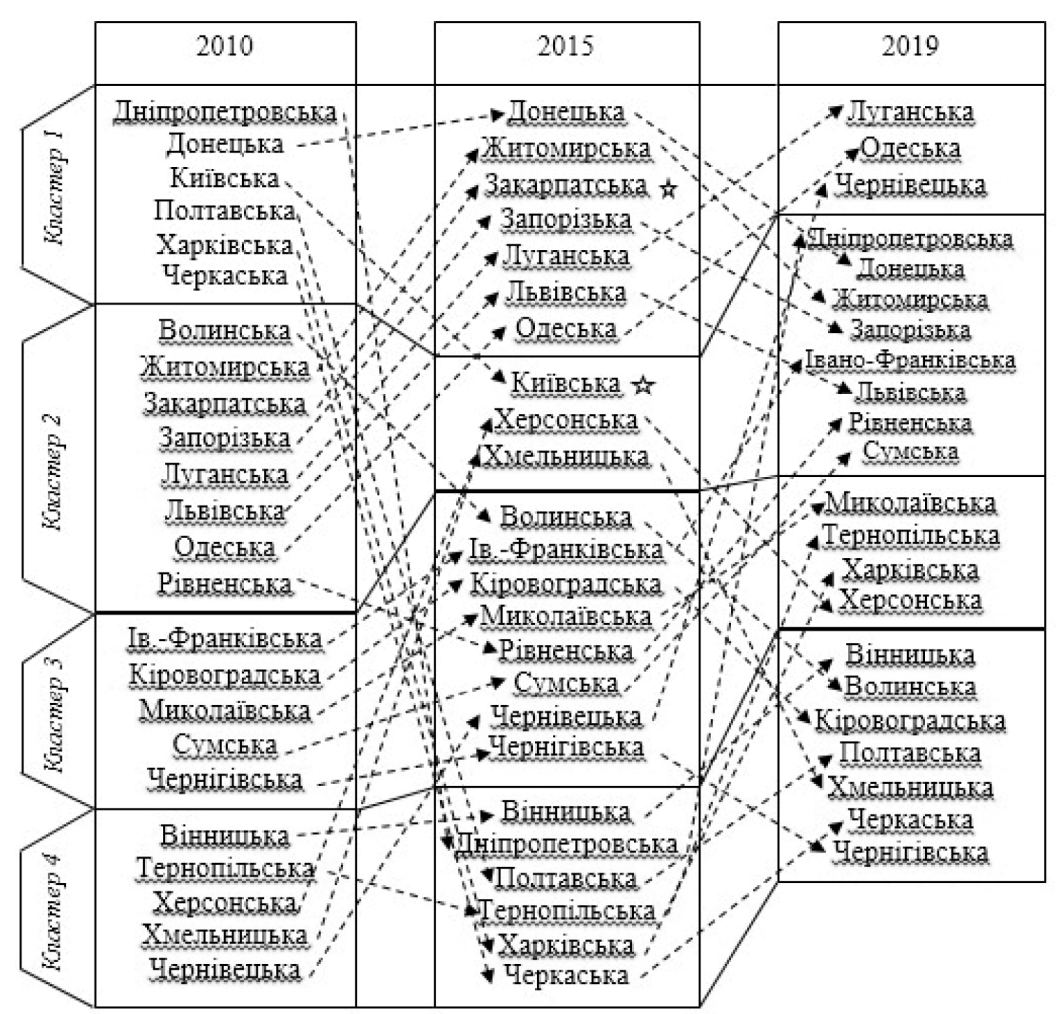

Рис. 3. Кластеризація регіонів Украӥни за схожими умовами розвитку підприємств аграрного сектору, щзо спеціалізуються на тваринництві [сформовано автором]

За результатами аналізу у 2019 р. виокремлюються 4 кластери:

I. Луганська, Одеська, Чернівецька області.

II. Дніпропетровська, Донецька, Житомирська, Запорізька, Івано-Франківська, Львівська, Рівненська, Сумська області.

III. Миколаївська, Тернопільська, Харківська, Херсонська області.

IV. Вінницька, Волинська, Кіровоградська, Полтавська, Хмельницька, Черкаська, Чернігівська області.

Закарпатська та Київська області, через прояв у 2019 р. специфічних характеристик функціонування підприємств, що спеціалізуються на тваринництві, не увійшли в жодний кластер.

Тому застосування багатофакторного статистичного (кластерного) аналізу дало змогу згрупувати регіони України за схожими умовами відносно розвитку підприємств аграрного сектора, що спеціалізуються на тваринництві. Це дає можливості для формування (розроблення) спільних ефективних організаційноекономічних механізмів стосовно активізації розвитку підприємств тваринництва, сприятливих для впровадження в межах кожного кластера (за умови врахування специфіки кожного регіону).

\section{Список використаних джерел}

1. Офіційний сайт Державної служби статистики України. URL: http://www.ukrstat.gov.ua.

2. Офіційне Інтернет-представництво Міністерства розвитку економіки торгівлі та сільського господарства України. URL: https://www.me.gov.ua/?lang=uk-UA.

\section{References}

1. State Statistics Service of Ukraine: Official site (2019). URL: http://www.ukrstat.gov.ua [in Ukrainian].

2. Ministry of Economic Development of Trade and Agriculture of Ukraine: Official Internet representation (2020). URL: http://minagro.gov.ua. [in Ukrainian]. 